\title{
Conservation of Mojave Desert springs and associated biota: status, threats, and policy opportunities
}

\author{
Sophie S. Parker ${ }^{1}$ (D) A Andy Zdon ${ }^{2} \cdot$ William T. Christian $^{3} \cdot$ Brian S. Cohen $^{4} \cdot$ \\ Maura Palacios Mejia ${ }^{5} \cdot$ Naomi S. Fraga $^{6} \cdot$ Emily E. Curd $^{5} \cdot$ Kiumars Edalati $^{5}$. \\ Mark A. Renshaw ${ }^{7}$
}

Received: 2 January 2020 / Revised: 29 July 2020 / Accepted: 19 November 2020 /

Published online: 5 December 2020

(C) The Author(s) 2020

\begin{abstract}
In arid landscapes where fresh water is a limiting resource, the expression of groundwater in springs sustains important landscape functions, globally-recognized biodiversity hotspots, and both aquatic endemic and wide-ranging terrestrial species. Desert springs and associated groundwater dependent ecosystems are threatened by unsustainable groundwater pumping, and the Mojave Desert has seen extinctions of species due to the human use and modification of springs. To support changes in policy and management that would address the vulnerabilities of springs to unsustainable groundwater extraction and other threats, a better understanding of current spring condition is needed. Here we present the results of a comprehensive survey of Mojave Desert springs including hydrological and ecological observations, and an eDNA pilot study. Together, these investigations provide information about the present status of Mojave Desert springs, conservation challenges that they face, and needs that must be met to protect them. We also provide an overview of the current state of federal and state policy that could be used to better manage these critical freshwater resources.
\end{abstract}

Keywords Freshwater - Biodiversity - Groundwater dependent ecosystems - Aquifer · Basin

Communicated by Karen E. Hodges.

Sophie S. Parker

sophie_parker@tnc.org

1 The Nature Conservancy, 445 S. Figueroa St., Suite 1950, Los Angeles, CA 90071, USA

2 Partner Engineering and Science, Inc., Santa Ana, CA, USA

3 The Nature Conservancy, Los Angeles, CA, USA

4 The Nature Conservancy, San Diego, CA, USA

5 University of California, Los Angeles, CA, USA

6 California Botanic Garden, Claremont, CA, USA

7 Oceanic Institute of Hawai'i Pacific University, Waimanalo, HI, USA 


\section{Introduction}

Fresh water is rare, covering just $0.8 \%$ of the Earth's surface. It is also ecologically important, as freshwater habitats support about $9.5 \%$ of all known animal species, and $65 \%$ of described species (Dudgeon et al. 2006; Balian et al. 2008). In arid landscapes, where fresh water is a limiting resource, the expression of groundwater in springs is often the only source of perennially-available surface water (Bogan 2014). Springs and the groundwater dependent ecosystems (GDEs) (Brown 2011) they support can be examples of small natural features-places that provide disproportionate ecological importance in comparison with their size (Hunter 2017). In deserts, these systems play an important role in supporting both aquatic biota and migratory and wide-ranging terrestrial animals (Davis et al. 2017). Springs and their associated GDEs also sustain a number of important landscape functions (Cohen et al. 2016), and are globally-recognized biodiversity hotspots (Suhling et al. 2006; Stevens and Meretsky 2008; Fensham et al. 2011; Cantonati et al. 2012; Murphy et al. 2015) that support locally endemic species. For example, the areas of highest local endemism in North America are found at desert springs (Stevens and Meretsky 2008).

Desert springs are threatened by human activity; they have been characterized as "endangered" (Shepard 1993) and are recognized as one of the most threatened ecosystems in the world (Kodric-Brown and Brown 2007). Human uses of groundwater can have a variety of impacts on springs (Zektser et al. 2005; Dudgeon et al. 2006). Groundwater pumping that causes aquifer levels to drop can result in a spring drying out, even if the amount of groundwater stored in the aquifer is still very large. In places where unsustainable groundwater extraction has depleted aquifers and caused springs to dry up, springdwelling and groundwater-dependent species have gone extinct (Ponder 1986; Danielopol et al. 2003; Strayer 2006). An example of these impacts can be seen in some areas of the Mojave Desert of California and Nevada (Fig. 1). For example, in Ash Meadows, Nevada, dropping groundwater levels and decreasing flow in springs has been caused by local agricultural extraction and use of groundwater (Pister 1991; Unmack and Minckley 2008). Impacts to GDEs caused by overdrafts in the Owens River Valley are due to water diversions and groundwater pumping by the Los Angeles Department of Water and Power (Zektser et al. 2005). Within the Great Basin region of North America, a portion of which is overlaid by the Mojave Desert Ecoregion (Madsen et al. 2002), at least 16 aquatic endemic species, subspecies, or distinctive populations have gone extinct since the late 1880s, including 12 fishes, three mollusks, and one aquatic insect (Sada and Vinyard 2002). While the reasons for these extinctions are varied, groundwater pumping and surface water flow diversions have both been identified as causes.

To support changes in policy and management that would address the vulnerabilities of desert springs and the biota they support to unsustainable groundwater extraction, a better understanding of the current condition of these springs is needed. Baseline conditions must be well-understood, a time horizon for management needs to be set (Sophocleus 2002), analysis and predictive modeling (Mirchi et al. 2019) should be used, and a well-designed monitoring system with trigger conditions must be put into place to allow for adaptive management (Gleeson et al. 2012) to avert harm. Identification of water resource impacts becomes problematic if initial baseline conditions are unknown or poorly understood.

Data regarding springs in the Mojave Desert is sparse, including biological inventories. The region's smaller springs frequently get overlooked in hydrologic investigations because their discharges are inconsequential to the overall water budget of the area being 
studied. In addition, some seeps and springs are not well mapped, so they are frequently overlooked in biological investigations. Such oversight is problematic when evaluating the sensitivity of critically important resources for plant diversity and wildlife. In addition, rapid human population growth and use for water resources in the Mojave Desert is an issue resulting in the need for a balancing of competing uses and priorities. These include providing water for human needs, preserving water-dependent ecological resources, and expanding commercial development including renewable energy generation facilities. The goal of our study is to investigate and provide a hydrological and ecological assessment of the Mojave Desert's springs, provide an analysis of the threats these ecosystems currently face, and discuss opportunities for policy and management into the future.

\section{Methods: spring assessment}

An assessment of springs and seeps in the Mojave Desert (Andy Zdon and Associates 2016) identified 436 springs (Fig. 1) across the California portion of the Mojave Desert Ecoregion on public lands managed by the Bureau of Land Management (BLM) and on lands owned by the Transition Habitat Conservancy, Mojave Desert Land Trust, Amargosa Conservancy, The Nature Conservancy, and Shoshone Village. We conducted an extensive data and literature review to obtain hydrogeologic, natural history, and cultural history information associated with these springs. Based on this information and ease of access, 312 of the 436 springs were field inspected between September 2015 and February 2016. Aerial imagery and information from various other sources was used to provide a remote overview of the 124 unvisited springs. Subsequent studies of many of these remaining springs have been conducted since the 2015-2016 spring survey and are discussed in Zdon et al. (2018) and Love and Zdon (2018).

Our field visits of springs included confirmation of geographic coordinates, estimation of surface discharge, and measurement of water quality parameters $(\mathrm{pH}$, temperature, conductivity and dissolved oxygen). We quantified spring discharge using a variety of methods, including visual estimation, measuring the time required to fill a container of known volume, use of a solid-state flow meter placed in a flowing channel of water, or measuring outfall characteristics from a pipe of known size. At all springs where surface water was present, water samples were analyzed for stable isotopes of oxygen $\left({ }^{18} \mathrm{O} /{ }^{16} \mathrm{O}\right)$ and hydrogen $\left({ }^{2} \mathrm{H} /{ }^{1} \mathrm{H}\right)$. At selected springs in the southeastern Mojave Desert (i.e., the Clipper Mountains) and in the west Mojave Desert (i.e., McDonald Well) radiocarbon $\left({ }^{14} \mathrm{C}\right)$, tritium $\left({ }^{3} \mathrm{H}\right)$ or other analytes were analyzed. All isotopes were analyzed using mass spectrometry.

We made flora and fauna observations for native and non-native species at each spring surveyed. The observations included making records of non-native plant species that could negatively impact local hydrology and ecology such as giant reed (Arundo donax) and saltcedar (Tamarix ramosissima). Special note was made when livestock, burro, or wild horses were present at springs, as non-native ungulates are known to have negative impacts on vegetation.

We sampled water from a single desert spring (Ahn Spring; Fig. 1) as part of a pilot study to test the use of Environmental DNA (eDNA) methods (Taberlet et al. 2012; Thomsen and Willerslev 2015) for surveying spring biota. The method of eDNA metabarcoding allows for DNA sequencing and assignment of multiple species to potentially detect for the presence of organisms at any given location based on an environmental sample (Deiner et al. 2015; Ruppert et al. 2019). Located in the Transition Habitat 
Fig. 1 Map of 436 springs on public lands managed by the Bureau of Land Management, and on private lands owned and managed by Transition Habitat Conservancy, Mojave Desert Land Trust, Amargosa Conservancy, and The Nature Conservancy across the Mojave Desert of California and southwestern Nevada. Springs that were visited during the 2015-2016 spring assessment are shown as black circles. Those shown as white diamonds were not visited. Particular springs of note are shown with slightly enlarged black circles and labelled with black numerals. These include Ahn Spring (1), Bonanza Spring (2), Chappo Spring (3), Chris Wicht Camp Spring (4), Dove Spring (5), Jack Spring (6), McDonald Well (7), Mesquite Spring (8), Poison Spring (9), Shoshone Spring (10), Tecopa Hot Spring (11), Tan Tan Well (12), and Willow Creek Camp Spring (13)

Conservancy's Portal Ridge Preserve, 18 miles west of Lancaster, California, Ahn Spring has been monitored with camera traps for 6 years, which allows us to test the accuracy and sensitivity of eDNA methods in detecting animals known to visit the spring.

For eDNA sampling, we took 3, 11 water samples on May 6, 2019, and filtered these immediately through $0.22 \mu \mathrm{m}$ Sterivex millipore filters (Millipore, MA, USA) using a Masterflex ${ }^{\circledR}$ L/S portable Peristaltic pump (Cole-Parmer, Vernon Hills, IL, USA). Samples were transported on ice and stored in a $-20^{\circ} \mathrm{C}$ freezer. We extracted DNA within 1 week of field sampling following the protocol developed by Spens et al. (2017), and removed inhibitors using the Zymo One Step Inhibitor removal Kit (Zymo Research, Irvine, California, USA). Library preparation methods followed Li et al. (2018); we amplified for two barcodes, a modified Vertebrate 16S (Ve16S; Evans et al. 2016), which targets vertebrates, and Plant Internal Transcribed Spacer 2 (PITS; Gu et al. 2013), which targets plants. Two rounds of PCR were utilized to amplify targeted fragments from eDNA extracts and prep libraries for Illumina sequencing (Olds et al. 2016). Samples also included a positive control mix of marine species, as they are not expected to be found in the Mojave Desert, and a PCR blank. The libraries were pooled to equal molar concentrations and the Illumina MiSeq sequencing run consisted of a $2 \times 300$ base pairs. The sequencing data was checked for quality and assigned taxonomy using the default parameters in the Anacapa Toolkit software (Curd et al. 2018). Sequence classification for the vertebrate (Ve16S) and plant (PITS) primers were crossed verified using the Web BLAST NCBI nucleotide database and the BOLD database (Ratnasigham and Hebert 2003).

\section{Results: current status of mojave desert springs}

Springs in the Mojave Desert constitute a diverse range of aquatic habitats and GDEs (Tables 1 and 2, Fig. 2). Field-assessed springs varied in their landscape context. While all were located on Bureau of Land Management or land trust lands, some were more distant from other springs. The springs of the Amargosa region (e.g., Shoshone Spring) and the Great Falls Basin in the Argus Range (Inyo County) regions can be thought of as "spring complexes." In contrast, other springs, such McDonald Well, provide the only reliable, free-flowing surface water for more than 500 square miles. A total of 27 springs (approximately $8 \%$ ) showed signs of livestock use, including erosion and/or compaction of soils, grazed and trampled vegetation, and deposition of manure.

Surface water was present at 145 of the 312 spring locations (Table 1). All spring locations where surface water was not observed had phreatophytic vegetation of widely varying amounts, indicating that the belowground water source was discharging through plant transpiration. These springs were noted as "dry-evapotranspiration only" to acknowledge that the simple notation of a spring being "dry" ignores that the spring is still discharging water and can lead to poor assumptions about the ecological importance of springs. Of the 145 springs with measurable flow, flows ranged from less than one gallon 


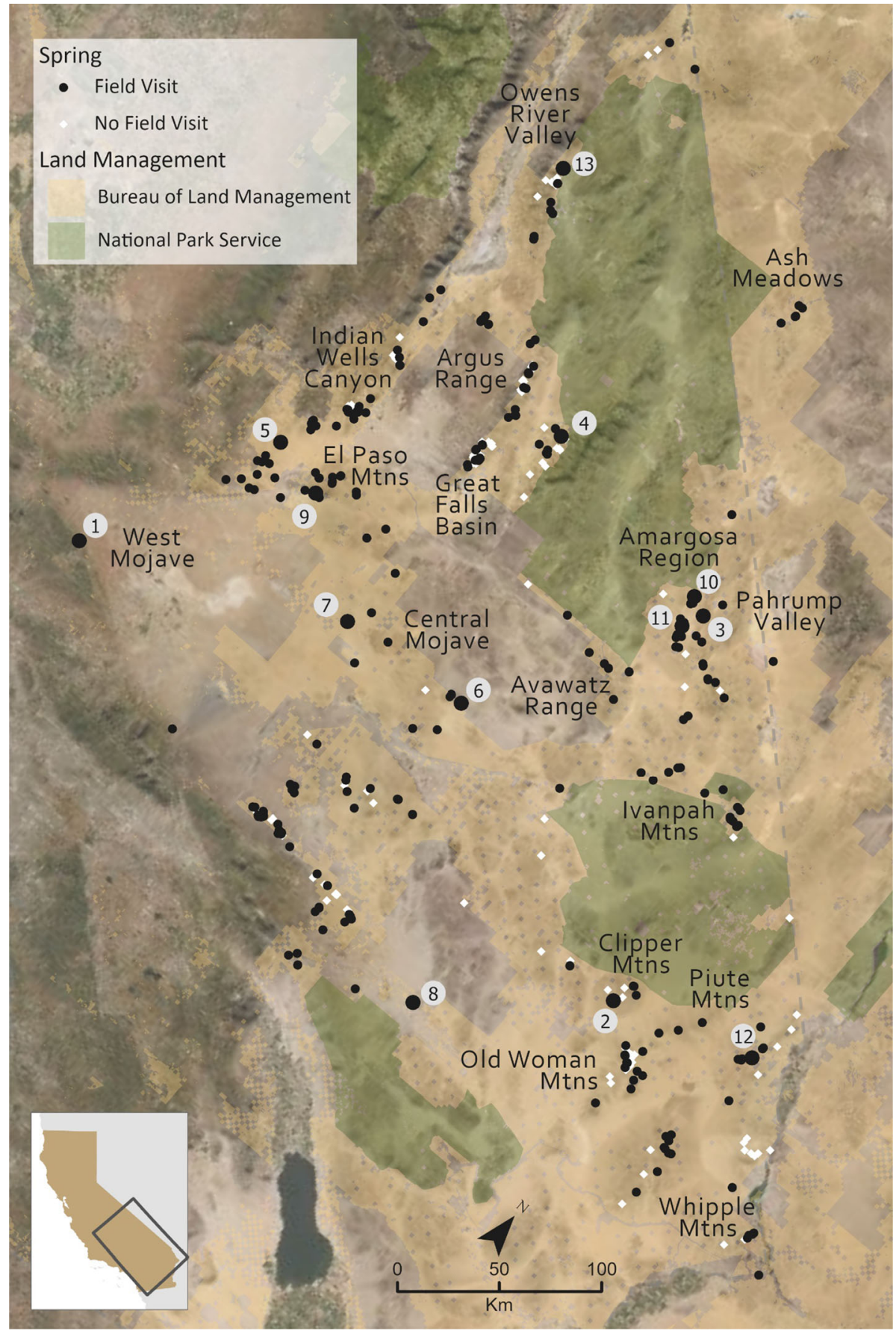




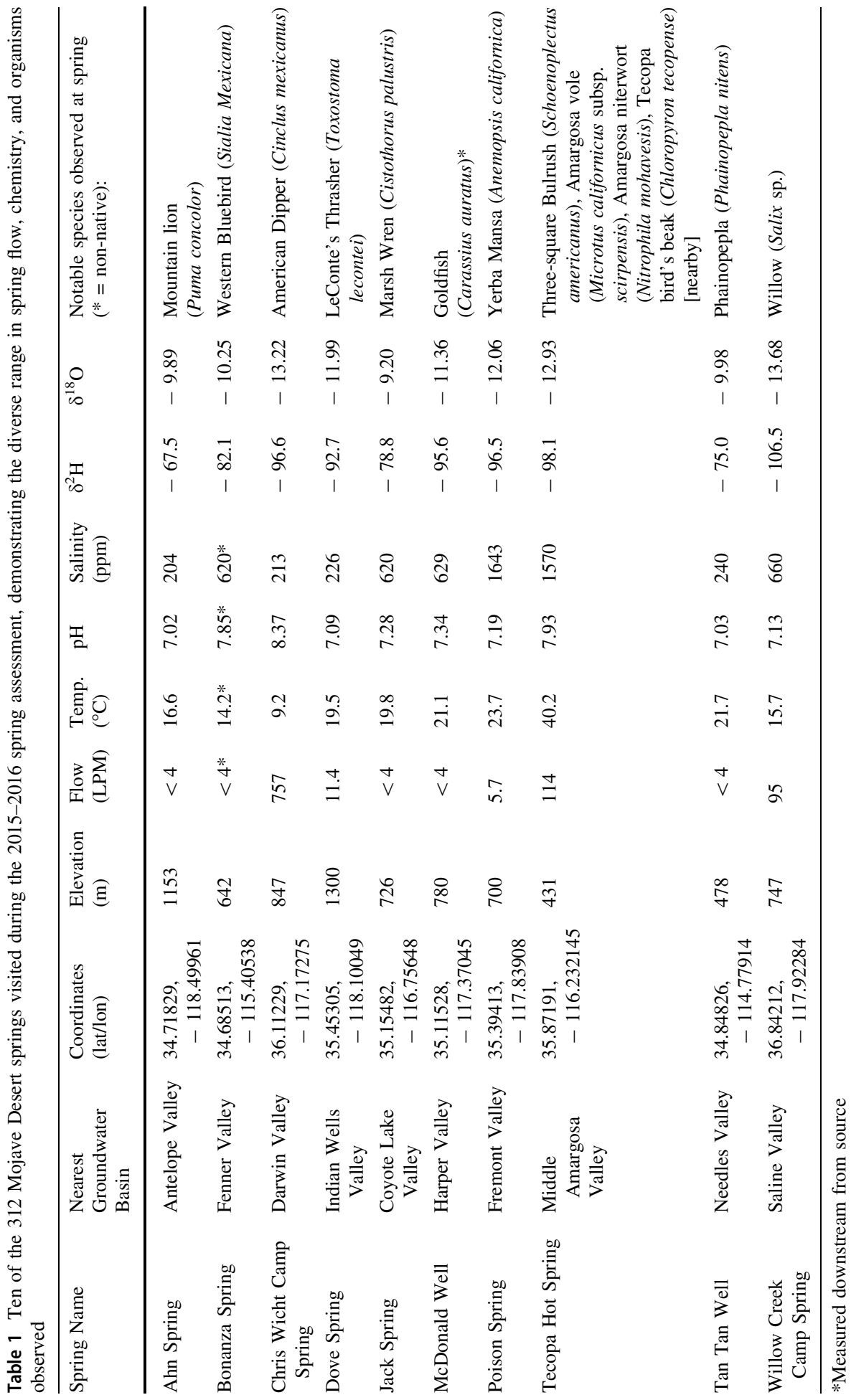


Table 2 Vertebrate and plant species detected from water samples at Ahn Springs using eDNA tecnhiques, compared with camera trap or field observations

\begin{tabular}{|c|c|c|c|c|}
\hline Scientific Name & $\begin{array}{l}\text { Common } \\
\text { Name }\end{array}$ & $\begin{array}{l}\% \\
\text { identity }\end{array}$ & Reads & Camera trap or observed \\
\hline Microtus levis & Vole sp. & 94.542 & 11,847 & Vole tunnel tracks observed in the area \\
\hline Neotoma macrotis & $\begin{array}{l}\text { Big eared } \\
\text { woodrat }\end{array}$ & 94.032 & 5920 & \\
\hline Dipodomys agilis & $\begin{array}{l}\text { Agile } \\
\text { kangaroo rat }\end{array}$ & 98.211 & 3439 & Kangaroo rats observed in the area \\
\hline Sciurus spadiceus & Squirrel sp. & 96.016 & 1960 & \\
\hline Odocoileus hemionus & Mule deer & 99.657 & 1817 & \\
\hline $\begin{array}{l}\text { Sceloporus } \\
\text { occidentalis }\end{array}$ & $\begin{array}{c}\text { Western } \\
\text { fenced } \\
\text { lizard }\end{array}$ & 98.529 & 596 & Observed in the area \\
\hline $\begin{array}{l}\text { Aphelocoma } \\
\text { californica }\end{array}$ & $\begin{array}{l}\text { California } \\
\text { Scrub Jay }\end{array}$ & 98.540 & 84 & \\
\hline Tamias umbrinus & Chipmunk sp. & 96.906 & 24 & Observed in the area \\
\hline Lepus californicus & $\begin{array}{r}\text { Black tailed } \\
\text { jackrabbit }\end{array}$ & 100 & 1046 & Observed in the area \\
\hline Anaxyrus punctatus & $\begin{array}{l}\text { Red spotted } \\
\text { toad }\end{array}$ & 100 & 154 & Not observed \\
\hline Peromyscus sp. & Rodent & 89.7 & 59 & Observed in the area \\
\hline Phacelia umbrosal & $\begin{array}{c}\text { Colorado } \\
\text { Desert } \\
\text { phacelia }\end{array}$ & 97.97 & 141 & $\begin{array}{l}\text { Related species based on geographic } \\
\text { distribution }\end{array}$ \\
\hline Quercus chrysolepis & $\begin{array}{l}\text { Canyon live } \\
\text { oak }\end{array}$ & 98.84 & 504 & Observed \\
\hline Nerium oleander & Oleander & 100 & 7268 & Not observed \\
\hline Chaenactis douglasii & $\begin{array}{l}\text { Douglas' } \\
\text { dustymaiden }\end{array}$ & 92.98 & 55 & $\begin{array}{l}\text { Related species based on geographic } \\
\text { distribution }\end{array}$ \\
\hline
\end{tabular}


Table 2 continued

\begin{tabular}{|c|c|c|c|c|}
\hline Scientific Name & $\begin{array}{l}\text { Common } \\
\text { Name }\end{array}$ & $\begin{array}{l}\% \\
\text { identity }\end{array}$ & Reads & Camera trap or observed \\
\hline Hordeum murinum & Wall barley & 100 & 14 & Potential unidentified grass species \\
\hline $\begin{array}{l}\text { Forestiera } \\
\quad \text { neomexicana }\end{array}$ & Desert Olive & 98.95 & 147 & Not observed \\
\hline
\end{tabular}

Images courtesy of Roy Dunn, Transition Habitat Conservancy

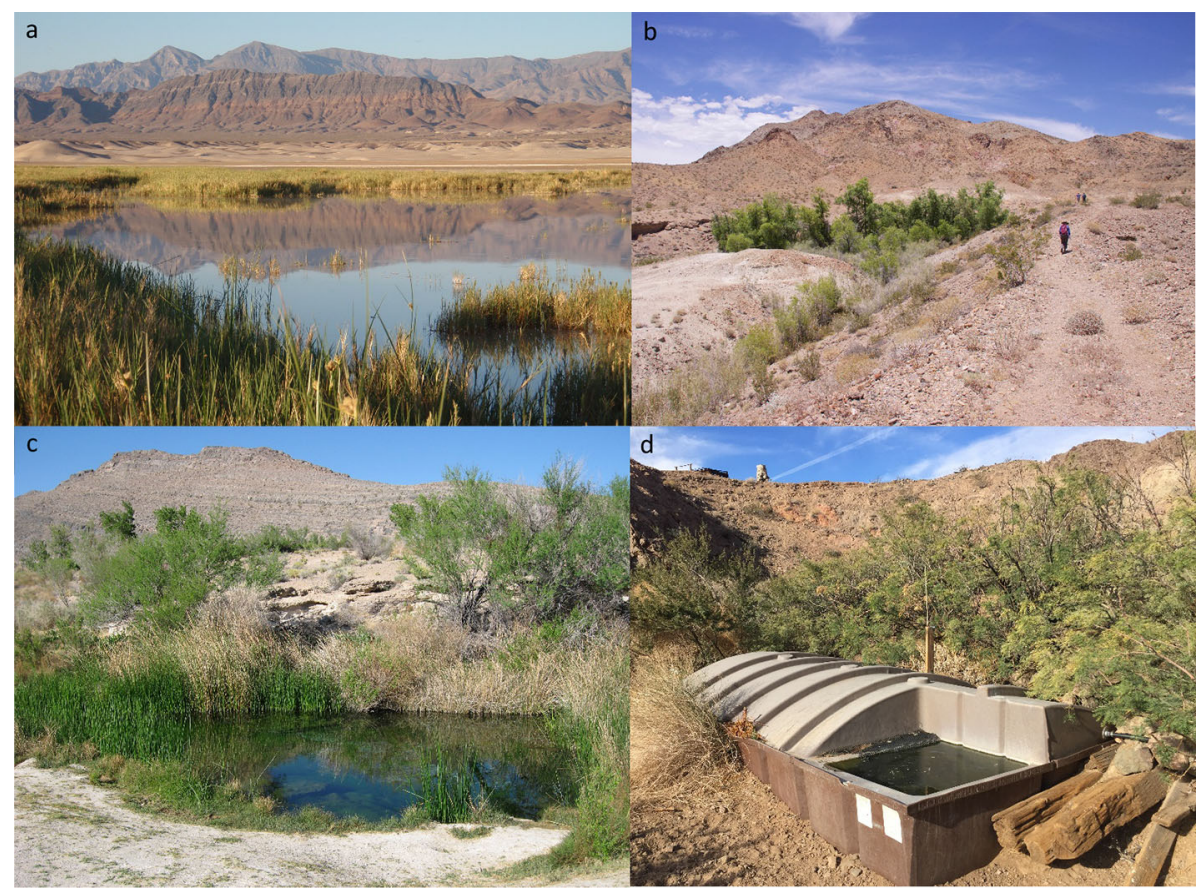

Fig. 2 Photographs of Mojave Desert springs. Borax Spring (a) and Bonanza Spring (b), are located in the California portion of the Mojave Desert, whereas Point of Rocks Spring (c), is part of a large spring complex in Ash Meadows National Wildlife Refuge in Nevada. The flow from Stone Canyon Spring (d) has been directed into a guzzler used by wildlife. Photo credits: William T. Christian (photos a, b, and c) and Andy Zdon (d)

per minute at 59 springs, up to 265 gallons per minute at Shoshone Spring in the Amargosa region. Pipes or other infrastructure were installed into a spring or seep face to enhance flow at 91 of 312 of the springs.

Of the 145 springs with surface water, $118(81.4 \%)$ contained fresh water with total dissolved solids (TDS) concentrations below $1000 \mathrm{mg} / \mathrm{l}$. The remaining 27 springs contained brackish water with TDS concentrations between 1000 and 10,000 mg/l. None of the springs had saline water (TDS over 10,000 mg/l). Spring water temperatures varied from $\sim 0{ }^{\circ} \mathrm{C}$ at French Madam Spring in the Argus Range (measured in December 2015 when the spring outfall was covered in an ice sheet) to $41.3{ }^{\circ} \mathrm{C}$ at Paradise Hot Spring in 
the Central Mojave region. Measurements of $\mathrm{pH}$ generally ranged from 6.21 at Lower Centennial Spring (South) to 9.71 at Borax Spring in the Amargosa region, with most of springs containing waters with a $\mathrm{pH}$ between 7.0 and 8.5.

The $\delta^{18} \mathrm{O}$ and $\delta \mathrm{D}$ abundances in spring waters reflect differences in the origin of precipitation across the Mojave Desert. In general, lower observed $\delta^{18} \mathrm{O}$ and $\delta \mathrm{D}$ isotope values in precipitation occur at higher elevations and with further distance from the California coast. However, across the Mojave Desert, total precipitation includes two different storm sources: winter maritime storms with lower (more negative) isotope values and summertime monsoonal storms with higher (less negative) isotope values. These variable sources yield a systematic difference in $\delta \mathrm{D}$ and $\delta^{18} \mathrm{O}$ abundance in accumulated precipitation across the Mojave Desert (Friedman et al., 1992). The spring water found in the southern Mojave Desert has higher (less negative) $\delta \mathrm{D}$ and $\delta^{18} \mathrm{O}$ values than that found in springs in the northern Mojave Desert. For $\delta \mathrm{D}$, the average isotope values for the northwest and northeast Mojave Desert are - 91.6 and - 86.4, respectively. In contrast, the average values for the southwest and southeast Mojave Desert are - 77.7 and - 71.6, respectively (Zdon et al. 2018). Where tested, age-dating of spring discharge using radiocarbon and tritium techniques has yielded ages from very recent seasonal (e.g., at Bird Spring) to apparent ages of more than 10,000 years at Bonanza Spring (Love and Zdon 2018).

Plant species present at springs included emergent aquatics such as watercress (Nasturtium officinale), and obligate phreatophytes that require groundwater and are common in GDEs such as chairmaker's bullrush (Schoenoplectus americanus), common reed (Phragmites australis), Fremont's cottonwood (Populus fremontii), southern cattail (Typha domingensis), western honey mesquite (Prosopis glandulosa subsp. torreyana), several willow species (Salix exigua, S. lasiolepis, S. laevigata, and S. goodingii), and willow baccharis (Baccharis salicina). Other native plant species that are known to occur both in areas of high groundwater and in uplands unassociated with GDEs and are considered facultative phreatophytes were recorded, including desert brickellbush (Brickellia desertorum), iodine bush (Suaeda nigra), saltbush (Atriplex sp.), and saltgrass (Distichlis spicata). Non-native plant species included those that are persisting from cultivation such as black locust (Robinia pseudoacacia) and black mulberry (Morus nigra), and plant species naturalizing from cultivated sources such as date palm (Phoenix dactylifera) and fan palms (Washingtonia sp.). Invasive species that are considered to have severe ecological impacts, such as saltcedar and giant reed, were also present (Cal-IPC 2019). Saltcedar was particularly abundant in the Whipple Wash area of the Whipple Mountains, in washes in the Old Woman Mountains, and areas along the Amargosa River where there is perennial water flow. Giant reed was noted at Ricky Spring in the Ivanpah Mountains, and in areas where eradication efforts have occurred in the past, such as Sacramento Spring and Bonanza Spring.

At springs where surface water was present, aquatic animals observed included macroinvertebrate species such as water striders (Family Gerridae), and freshwater snails (including both Physa sp. and Pyrgulopsis sp.). Amphibians were commonly observed, including red-spotted toad (Anaxyrus punctatus). During September and October, neotropical migratory birds were observed at nearly every spring where surface water was present. Mammals observed during the survey included desert bighorn sheep (Ovis canadensis nelsoni), American badger (Taxidea taxus) and a bobcat (Lynx rufus). Mountain lion (Felix concolor) sign was observed in various locations, with bobcat and coyote (Canis latrans) scat and tracks plentiful. Desert kit fox (Vulpes macrotis) tracks were observed in the Avawatz Range, and American black bear (Ursus americanus) tracks and scat were observed at Siebert Spring in the eastern Sierra Nevada in Indian Wells Canyon. 
Other special status species were observed during the course of the field work (Table 1), including live desert tortoise in three locations: on the alluvial fan below the Great Falls Basin spring area, on the alluvial fan south of Hummingbird Spring in the Clipper Mountains, and south of Blackwater Well and north of McDonald Well in the West Mojave. A desert tortoise shell at Pothole Seep in the Argus Range was also found. Numerous Least Bell's Vireo (Vireo bellii pusillus) were observed singing along Willow Creek; this species was also present at Vole Spring and Shoshone Spring. One Inyo California Towhee (Pipilo crissalis eremophilus) was observed in Great Falls Basin near Twin Springs.

Many of the species we detected during field observations or with camera traps were also detected by eDNA techniques (Table 2). However, the suite of species detected using each method varied, and the percent identity of eDNA detection of species varied. Two plant species - the native desert olive (Forestiera pubescens) and the non-native oleander (Nerium oleander) were observed using eDNA techniques, but were not observed in the field at Ahn Spring. A wide-ranging mammal and apex predator at this spring, the Mountain Lion, has been observed in camera trap photos many times, but was not detected using eDNA techniques.

\section{Discussion}

\section{Conservation challenges}

In recent decades, researchers have repeatedly and increasingly named groundwater extraction (and associated aquifer drawdown) by humans as a major, and frequently the most important, threat to desert springs (e.g., Shepard 1993; Sada and Vinyard 2002; Deacon et al. 2007; Unmack and Minckley 2008; Fensham et al. 2011; Davis et al. 2013, 2017; Bogan et al. 2014). In the Mojave Desert, our study sets a baseline for understanding spring flow for many springs where this has not been recorded in the past. But for springs where historical records or more recent observations exist, it is evident that many springs appear to be impacted by regional groundwater use by human communities. Spring depletions due to regional groundwater use can occur slowly, over very long periods of time, making depletions particularly difficult to observe and manage. The depletion of several springs in the Amargosa region provides one example. To the east and north of the Amargosa River Basin, pumping of groundwater in the Pahrump and Amargosa Valleys of Nevada and nearby landscapes may be impacting the Amargosa groundwater system. Records from Pahrump Valley indicate that groundwater pumping there increased more than an order of magnitude over less than a decade, growing from $1,428,656 \mathrm{~m}^{3}$ year $^{-1}$ in 1959 to $59,106,184 \mathrm{~m}^{3}$ year $^{-1}$ in 1968 . Since that time, groundwater pumping has gradually decreased in Pahrump Valley, and in 2011, total groundwater pumping was $16,458,514 \mathrm{~m}^{3}$ year $^{-1}$, the lowest pumpage recorded since 1959 . While groundwater levels in the Pahrump Valley have steadily declined since 1959, impacts to springs in the Middle Amargosa Basin have largely gone unmeasured. Thompson (1929) estimated flow at Yeoman Spring (now known as Chappo Spring), and noted that settlers had stated, "a warm or hot spring at the ranch of Alec Yeoman, about 5 miles southeast of Shoshone, is said to flow 10 miner's inches (approximately 110 gallons per minute). It has been used for irrigation." Early reports indicate that nearby Resting Springs had flows of up to 250 gallons per minute. Today, both springs flow at rates substantially lower than those historically reported. There is presently no obvious flow at the source of Chappo 
Spring, only standing water in a small pool (Andy Zdon and Associates 2016). Additionally, groundwater levels in a monitoring well installed north of Shoshone Spring are very slowly decreasing over time. This may indicate that there is a slow, currently unmeasurable, decrease in spring flow at Shoshone Spring that would be only be identifiable after several decades and with well-engineered monitoring infrastructure. While the changes at some springs may be the result of spring modification and additional vegetation uptake, it is likely that spring flow in the Middle Amargosa Basin has been affected by past pumping in Pahrump Valley.

Impacts from groundwater pumping in the Middle Amargosa Basin are significant because of the presence of exceptional biodiversity associated with spring flows and GDEs (Parker et al. 2018). There are 26 taxa known to be endemic to Ash Meadows Wildlife Refuge (Sada 1990), but several other rare plant and animal species occur in the Middle Amargosa Basin outside of the Refuge. Rare plant species associated with GDEs outside of the refuge include alkali mariposa lily (Calochortus striatus), Amargosa niterwort (Nitrophila mohavensis), Ash Meadows gumplant (Grindelia fraxinipratensis), spring loving centaury (Zeltnera namophila), and Tecopa bird's beak (Chloropyron tecopense). Endemic animals such the Amargosa vole (Microtus californicus subsp. scirpensis) and Shoshone pupfish (Cyprinodon nevadensis subsp. shoshone) are restricted to spring-fed habitats.

Springs in other areas of the Mojave Desert have seen similar declines in water flow when compared with historic conditions. We found that Mesquite Springs had no standing water, and the only plant species present was western honey mesquite (Andy Zdon and Associates 2016). However, there may have been a broader suite of plants growing at the site in the past. Historical records indicate that "water from the flowing wells was piped directly into the house [in 1934]" (Keeling 1976), and "wild roses, as well as wild grapes, grew profusely at Mesquite Springs, a matter that has been remembered throughout the years by several of the first women to pioneer this section" (Wynn 1963).

In addition to pumping of groundwater for human uses, development of springs through the addition of pipes, troughs, and other infrastructure can also negatively impact spring flow. These flow enhancements are commonly made for livestock, wildlife, or mining use. This approach is similar to approaches used in geotechnical remedial activities to drain off groundwater and enhance ground stability landslide areas. In both cases, the installation of hardware in springs can lead to dewatering the saturated systems. With springs, the hardware can yield flow that cannot be sustained naturally. We saw an example of this during our study at Mesquite Springs along the south slope of the El Paso Mountains.

Spring waters and GDEs supported by spring flow are degraded by a variety of human activities, including livestock grazing, wild horse and burro presence, and adverse human use (e.g., off-highway vehicle and other recreational use). Waters are polluted and contaminated directly by these activities, and indirectly when spring-adjacent lands endure erosion and increased rates of sedimentation and nutrient and pollutant loading (Unmack and Minckley 2008). We found that some springs on livestock allotments on BLM lands in the California Mojave (i.e., Mound and Vaughn Springs) were in relatively good condition, indicating active management on the part of ranchers of public lands used as grazing allotments, while others were trampled and highly grazed (i.e., Barrel Spring in the Piute Mountains). While fencing can be used to help mitigate the negative impacts of livestock grazing, grazing exclusions must be managed with care. Fencing to exclude grazers has been found to lead to the development of dense vegetation growth, shading of waters (Shepard 1993), and may exclude wide-ranging mammals from using springs as water source. Researchers working in Ash Meadows, the largest spring complex in the Mojave 
Desert, have found that in order to maintain native biodiversity and endemic biota, management of some small desert springs needs to include disturbance to mimic the actions of large Pleistocene megaherbivores and aboriginal human communities that are no longer present (Kodric-Brown and Brown 2007).

The invasion of non-native species and the extirpation or extinction of native species also impact the conservation value of desert springs. Our study found evidence of a broad variety of non-native species at the springs we surveyed in the California Mojave Desert, but a different suite of species was detected using each method (i.e., field observations, camera trapping, or eDNA). This result demonstrates the potential to enhance our ability to identify and study the true community of organisms at Mojave Desert springs by combining a number of different techniques. Use of multiple techniques may also decrease the pitfalls associated with each method. For example, camera traps have restrictions on photographic range and detectable size of species (Ishige et al. 2017), whereas eDNA methods can give false positives (Ficetola et al. 2016). Our study underscores the need for a better genetic reference database for the community of organisms associated with Mojave Desert springs, which, like many understudied ecosystems, had low percent identities at the species level (Wangensteen et al. 2018; Sinniger et al. 2016), particularly for mammals and plants.

As noted by Davis et al. 2017, the threats facing desert springs are additive and interacting, posing a major challenge for managers. In addition to the proximal threats of water extractions and diversions, habitat degradation, invasive species, and global changes threaten to exacerbate current impacts to desert springs. As the climate warms and the human population grows, desert areas will be under increasing pressure to extract groundwater and develop surface diversions in order to support human uses (Vicuna 2007). This is likely to adversely impact the conservation value of desert springs by increasing the drought stress for native species within GDEs. This may cause a contraction in the size of spring-fed GDEs and the number, or abundance, of obligate phreatophyte plant species contained within them. Rising water temperatures and the growing competitive advantage of more drought-tolerant non-native species may negatively impact Mojave Desert fishes and other native aquatic organisms in desert springs (Archer and Predick 2008), as some of these native species are living near their physiological limits and are vulnerable to shifts in community composition.

Climate change will also affect springs in the Mojave Desert as temperature increases evaporative processes and likely decreases groundwater recharge that ultimately surfaces as spring discharge (Meixner et al. 2016). Tagestad et al. (2016) identified 30 to 40-year long wet/dry cycles in the Mojave Desert, including an early-century wet period (1905-1946), a mid-century drought (1947-1975), and a later-century wet period (1975-2010). Annual precipitation has generally been below the 1975-2010 average since 2010. As we enter what may be a multi-decade drier than normal period (based on these trends), the imprint of climate change on these drier than normal periods with anticipated increasing competition for water resources will add to the vulnerability of springs and GDEs.

\section{Policy implications}

Given the severe consequences of unsustainable groundwater extraction, and in recognition of the importance of groundwater to the health and survival of human and natural communities, the State of California put into place the Sustainable Groundwater Management 
Act (SGMA) in 2014. This law limits the amount of pumping that can occur from aquifers to prevent undesirable impacts to beneficial uses of groundwater, including impacts to GDEs (Rohde et al. 2017). The enactment of the SGMA is significant; after more than a century of essentially no regulation of groundwater extraction, California state law now recognizes the needs of plants and wildlife for water, alongside providing for human uses such as domestic, irrigation and industrial consumption of water.

Unfortunately, very few Mojave Desert basins in California are covered under SGMA. This leaves over 1 million acres (nearly half) of the GDEs in California (Howard and Merrifield 2010) — those found in the Mojave and Sonoran deserts-vulnerable to continued unsustainable extraction. For the great majority of desert basins, and especially remote desert basins where aquifers support many critical springs, there is no effective limitation on groundwater withdrawals apart from county ordinances that have usually proved inadequate to limit unsustainable pumping. As one example, the Cadiz Valley Water Conservation, Recovery and Storage Project proposes to grossly overdraft a Mojave desert basin, pumping and exporting groundwater from an aquifer that supports vital springs. Despite the proposed overdraft and ecological impacts, SGMA does not apply to the basin. A county groundwater management ordinance that would have precluded overdrafting was waived after the project agreed to supply water to the county.

While SGMA may not cover Mojave Desert basins in California, other protections exist at the state level. The California Department of Fish and Wildlife (DFW) and State Lands Commission (SLC) have specific statutory duties to protect resources. DFW must protect the fish, wildlife and natural resources of the state. This duty extends beyond protection for listed species to all biological resources of the state. The SLC is obligated to maximize the economic value of state-owned lands across California's Mojave and Sonoran Deserts. If groundwater resources under these desert lands are depleted, the value of state-owned lands is likely to be greatly reduced for most potential uses. California's water laws require property owners sharing access to a groundwater aquifer to equitably share the water, giving the SLC the legal right to seek limitations on excessive pumping, even on private or public lands where it would reduce the value of state-owned lands.

Federal limitations on groundwater pumping to protect GDEs have not been commonly asserted in agency land use decisions. Some exceptions exist, primarily where federally threatened or endangered species are dependent on flows from a groundwater aquifer. At Ash Meadows National Wildlife Refuge and Devils Hole, a disjunct unit of Death Valley National Park, federal agencies have asserted rights to control groundwater extraction, but usually only where the federal rights precede the grant of conflicting state water rights, and where it is quite clear that the listed species is at risk from groundwater pumping. An example of the successful assertion of the primacy of federal water rights over state rights is described in the landmark 1976 case of Cappaert v. United States, where the US Supreme Court ruled that state water rights were subservient to the federal reserved water rights needed to protect the endangered Devils Hole pupfish (Cyprinodon diabolis).

Beyond these limited exceptions, federal policy has traditionally deferred virtually complete control over groundwater resources to states (Leshy 2004, 2008). However, this may be changing. BLM's most recent desert resource management plan amendments recognize more clearly the agency's duties under the Federal Land Policy and Management Act of 1976 to protect GDEs, especially in the Mojave and Sonoran Desert. The Desert Renewable Energy Conservation Plan (DRECP), an amendment to the California Desert Conservation Area Plan instituted by the agency primarily to provide for the siting and regulation of desert renewable energy facilities, incorporates limitations on groundwater use, invoking protection of springs, seeps and wetlands and their associated species, 
irrespective of whether those species are listed as threatened or endangered. These provisions require extensive hydrogeologic knowledge, impose predictive modeling and monitoring of the effects of pumping, and protect GDEs. The groundwater provisions of the DRECP have yet to be widely employed, but they promise to make significant, positive changes in BLM's handling of actions affecting groundwater and desert springs.

Lastly, application of the Public Trust Doctrine under both federal and state law may be expanded to encompass protection of desert springs and GDEs. For example, in the 1983 case National Audubon Society v. Superior Court, the Supreme Court of California ruled that California's public trust doctrine required reduction of water extraction from tributaries of Mono Lake to maintain the lake's functional ecosystems. In a 2018 case, Environmental Law Foundation v. State Water Resources Control Board, California's Supreme Court ruled that groundwater pumping adjacent to the Scott River was subject to limitation based on the public trust doctrine. It appears that the public trust doctrine could therefore be expanded further to include desert groundwater aquifer systems, springs, and the GDEs they support.

Existing state and federal agency legislative and regulatory provisions can and should be expanded to better ensure the long-term sustainability of wildlife and natural communities. In the Mojave Desert, maintaining springs and seeps through careful regulation of pumping from source aquifers is of cardinal importance to life. Obtaining adequate knowledge about springs and their sources is the first step in delivering on that important project.

\section{Conclusion}

Effective spring monitoring is needed to ensure the long-term viability of desert springs and to protect the biodiversity they support. Recording both biotic and abiotic conditions for springs is critical because springs and their associated flora and fauna can be particularly susceptible to small changes in groundwater elevation, and in the Mojave Desert, these changes can occur very slowly (Andy Zdon and Associates 2014). Our study demonstrates that the need for monitoring in the Mojave Desert is particularly acute, given that we established a hydrological and ecological baseline for many springs even as human uses of groundwater continue to take place. Our study, while valuable for future comparisons, is a "snapshot in time" of conditions that continue to change. Unfortunately, the identification of hydrological or biological change at a spring can occur too late to affect meaningful change in water management to preserve a spring. This is because the slow movement of groundwater can result in groundwater levels continuing to drop even after pumping has ceased. Continued spring monitoring is therefore critical, and an expanded network of monitoring, including at monitoring wells away from spring areas, will be needed to protect the springs of the Mojave Desert. Additionally, while many spring areas on public lands are protected by conservation designations such as Wilderness or National Monument status, impacts to these springs may occur from stresses to aquifer systems many miles away, and those impacts may occur over decades. Therefore, a periodic monitoring program for the entire region will be required to understand these spring systems and identify future attributable impacts in a defensible manner.

Acknowledgements The authors wish to thank The Nature Conservancy for financial support of the writing process, and the Transition Habitat Conservancy, Bureau of Land Management, and The Nature Conservancy for funding the 2015-2016 Mojave Desert Spring Survey. 


\section{Compliance with ethical standards}

Conflict of interest The authors declare that they have no conflict of interest.

Open Access This article is licensed under a Creative Commons Attribution 4.0 International License, which permits use, sharing, adaptation, distribution and reproduction in any medium or format, as long as you give appropriate credit to the original author(s) and the source, provide a link to the Creative Commons licence, and indicate if changes were made. The images or other third party material in this article are included in the article's Creative Commons licence, unless indicated otherwise in a credit line to the material. If material is not included in the article's Creative Commons licence and your intended use is not permitted by statutory regulation or exceeds the permitted use, you will need to obtain permission directly from the copyright holder. To view a copy of this licence, visit http://creativecommons.org/licenses/by/4.0/.

\section{References}

Andy Zdon and Associates (2014) State of the Basin Report: Amargosa River Basin - Inyo and San Bernardino Counties, California and Nye and Clark Counties, Nevada. Report prepared for Amargosa Conservancy

Andy Zdon and Associates (2016) Mojave Desert Springs and Waterholes: results of the 2015-2016 Mojave Desert spring survey. Report prepared for Transition Habitat Conservancy, The Bureau of Land Management, and The Nature Conservancy

Archer SR, Predick KI (2008) Climate change and ecosystems of the southwestern United States. Rangelands 30:23-28

Balian EV, Lévêque C, Segers H, Martens K (2008) The Freshwater Animal Diversity Assessment: an overview of the results. Hydrobiologia 595:627-637

Bogan MT, Noriega-Felix N, Vidal-Aguilar SL, Findley LT, Lytle DA, Gutiérrez-Ruacho OG, AlvaradoCastro JA (2014) Biogeography and conservation of aquatic fauna in spring-fed tropical canyons of the southern Sonoran Desert, Mexico. Biodivers Conserv 23:2705-2748

Brown J, Bach L, Aldous A, Wyers A, DeGagné J (2011) Groundwater-dependent ecosystems in Oregon: an assessment of their distribution and associated threats. Front Ecol Environ 9:97-102

Cantonati M, Fureder L, Gerecke R, Juttner I, Cox EJ (2012) Crenic habitats, hotspots for freshwater biodiversity conservation: towards an understanding of their ecology. Freshw Sci 31:463-480

Cohen MJ, Creed IF, Alexander L, Basu NB, Calhoun AJ, Craft C, D’Amico E, DeKeyser E, Fowler L, Golden HE, Jawitz JW, Kalla P, Kirkman LK, Lane CR, Lang M, Leibowitz SG, Lewis DB, Marton J, McLaughlin DL, Mushet DM, Raanan-Kiperwas H, Rains MC, Smith L, Walls SC (2016) Do geographically isolated wetlands influence landscape functions? Proc Natl Acad Sci USA 113:1978-1986

Curd EE, Gold Z, Kandlikar GS, Gomer J, Ogden M, O’Connell T, Pipes L, Schweizer TM, Rabichow L, Lin M (2018) Anacapa Toolkit: an environmental DNA toolkit for processing multilocus metabarcode datasets. Methods Ecol Evol 10:1469-1475

Danielopol DL, Griebler C, Gunatilaka A, Notenboom J (2003) Present state and future prospects for groundwater ecosystems. Environ Conserv 30:104-130

Davis J, Pavlova A, Thompson R, Sunnucks P (2013) Evolutionary refugia and ecological refuges: key concepts for conserving Australian arid zone freshwater biodiversity under climate change. Glob Change Biol 19:1970-1984

Davis JA, Kerezsy A, Nicol S (2017) Springs: conserving perennial water is critical in arid landscapes. Biol Conserv 211:30-35

Deacon JE, Williams AE, Williams CD, Williams JE (2007) Fueling population growth in Las Vegas: how large-scale groundwater withdrawal could burn regional biodiversity. Bioscience 57:688-698

Deiner K, Walser JC, Mächler E, Altermatt F (2015) Choice of capture and extraction methods affect detection of freshwater biodiversity from environmental DNA. Biol Conserv 183:53-63

Dudgeon D, Arthington AH, Gessner MO, Kawabata Z-I, Knowler DJ, Lévêque C, Naiman RJ, PrieurRichard A-H, Soto D, Stiassny MLJ, Sullivan CA (2006) Freshwater biodiversity: importance, threats, status and conservation challenges. Biol Rev 81:163-182

Evans NT, Olds BP, Renshaw MA, Turner CR, Li Y, Jerde CL, Mahon AR, Pfrender ME, Lamberti GA, Lodge DM (2016) Quantification of mesocosm fish and amphibian species diversity via environmental DNA metabarcoding. Mol Ecol Res 16:29-41

Fensham RJ, Silcock JL, Kerezsy A, Ponder W (2011) Four desert waters: setting arid zone wetland conservation priorities through understanding patterns of endemism. Biol Conserv 144:2459-2467 
Ficetola GF, Taberlet P, Coissac E (2016) How to limit false positives in environmental DNA and metabarcoding? Mol Ecol Res 16:604-607

Friedman I, Smith GI, Gleason JD, Warden A, Harris JM (1992) Stable isotope composition of waters in southeastern California. 1 Modern precipitation. J Geophys Res 97:5795-5812

Gillespie J, Nelson ST, Mayo AL, Tingey DG (2012) Why conceptual groundwater flow models matter: a trans-boundary example from the arid Great Basin, western USA. Hydrogeol J 20:1133-1147

Gleeson T, Alley WM, Allen DM, Sophocleous MA, Zhou Y, Taniguchi M, VanderSteen J (2012) Towards sustainable groundwater use: setting long-term goals, backcasting, and managing adaptively. Groundwater 50:19-26

Gu W, Song J, Cao Y, Sun Q, Yao H, Wu Q, Chao J, Zhou J, Xue W, Duan J (2013) Application of the ITS2 region for barcoding medicinal plants of Selaginellaceae in Pteridophyta. PLoS ONE 8:e67818

Hereford R, Webb RH, Longpre CI (2004) Precipitation history of the Mojave Desert region, 1893-2001. U.S. Geological Survey Fact Sheet 117-03

Howard J, Merrifield M (2010) Mapping groundwater dependent ecosystems in California. PLoS ONE 5(6):e11249

Hunter ML, Acuña V, Bauer DM, Bell KP, Calhoun AJ, Felipe-Lucia MR, Fitzsimons JA, González E, Kinnison M, Lindenmayerk D, Lundquist CJ, Medellin RA, Nelson EJ, Poschlod P (2017) Conserving small natural features with large ecological roles: a synthetic overview. Biol Conserv 211:88-95

Ishige T, Miya M, Ushio M, Sado T, Ushioda M, Maebashi K, Yonechi R, Lagan P, Matsubayashi H (2017) Tropical-forest mammals as detected by environmental DNA at natural saltlicks in Borneo. Biol Conserv 210:281-285

Keeling PJ (1976) Once Upon a Desert: A Bicentennial Project. Mojave River Valley Museum Association.

Kodric-Brown A, Brown JH (2007) Native fishes, exotic mammals, and the conservation of desert springs. Front Ecol Environ 5:549-553

Leshy JD (2004) the federal role in managing the nation's groundwater. Hastings Environ Law J 11:1-19

Leshy JD (2008) Interstate groundwater resources: the federal role. Hastings Environ Law J 14:1475-1498

Li Y, Evans NT, Renshaw MA, Jerde CL, Olds BP, Shogren AJ, Deiner K, Lodge DM, Lamberti GA, Pfrender ME (2018) Estimating fish alpha-and beta-diversity along a small stream with environmental DNA metabarcoding. Metabarcod Metagenomics 2:e24262

Love AH, Zdon A (2018) Use of radiocarbon ages to narrow groundwater recharge estimates in the southeastern Mojave Desert, USA. Hydrology 5:51

Madsen DB, Hershler R, Currey DR (2002) Introduction. Pages 30-52 in Hershler R, Madsen DB, Currey D, eds. Great Basin aquatic systems history. Smithsonian Contributions to the Earth Sciences no. 33.

Meixner T, Manning AH, Stonestrom DA, Allen DM, Ajami H, Blasch KW, Brookfield AE, Castro CL, Clark JF, Gochis DJ, Flint AL, Neff KL, Niraula R, Rodell M, Scanlon BR, Singha K, Walvoord MA (2016) Implications of projected climate change for groundwater recharge in the western United States. J Hydrol 534:124-138

Mirchi A, Watkins D, Madani K (2010) Modeling for watershed planning, management, and decision making. Watersheds: management, restoration and environmental impact. Nova Science Publishers, Hauppauge

Morris BL, Lawrence AR, Chilton PJC, Adams B, Calow RC, Klinck BA (2003) Groundwater and its susceptibility to degradation: a global assessment of the problem and options for management Vol. 3. United Nations Environment Programme.

Murphy NP, Guzik MT, Cooper SJ, Austin AD (2015) Desert spring refugia: museums of diversity or evolutionary cradles? Zool Scr 44:693-701

Olds BP, Jerde CL, Renshaw MA, Li Y, Evans NT, Turner CR, Deiner K, Mahon AR, Brueseke MA, Shirey PD (2016) Estimating species richness using environmental DNA. Ecol Evol 6:4214-4226

Parker SS, Pauly GB, Moor J, Fraga NS, Knapp JJ, Principe Z, Brown BV, Randall JM, Cohen BS, Wake TA (2018) Adapting the bioblitz to meet conservation needs. Conserv Biol 32:1007-1019. https://doi. org/10.1111/cobi.13103

Pister EP (1991) Desert fishes council: catalyst for change. In: McKinley WL, Deacon JE (eds) Battle against extinction: native fish management in the American West. University of Arizona Press, Arizona

Ponder WF (1986) Mound springs of the great artesian basin. In: Deckker PD, Williams WD (eds) Limnology in Australia. Springer, New York

Rohde MM, Froend R, Howard J (2017) A global synthesis of managing groundwater dependent ecosystems under sustainable groundwater policy. Groundwater 55:293-301

Ruppert KM, Kline RJ, Rahman MS (2019) Past, present, and future perspectives of environmental DNA (eDNA) metabarcoding: a systematic review in methods, monitoring, and applications of global eDNA. Glob Ecol Conserv 17:e00547 
Sada DW (1990) Recovery Plan for the Endangered and Threantened Species of Ash Meadows, Nevada. https://www.fws.gov/carlsbad/SpeciesStatusList/RP/19900928_RP_Ash\%20Meadows\%20Plants\% 20and\%20Fish.pdf. accessed 18 Nov 2019

Sada DW, Vinyard GL (2002) Anthropogenic changes in historical biogeography of Great Basin aquatic biota. In Hershler R, Madsen DB, Currey D, (eds) Great Basin aquatic systems history. Smithsonian Contributions to the Earth Sciences no. 33.

Shepard WD (1993) Desert springs-both rare and endangered. Aquat Conserv 3:351-359

Sinniger F, Pawlowski J, Harii S, Gooday AJ, Yamamoto H, Chevaldonné P, Cedhagen T, Carvalho G, Creer S (2016) Worldwide analysis of sedimentary DNA reveals major gaps in taxonomic knowledge of deep-sea benthos. Front Mar Sci 3:92

Sophocleous M (2002) Interactions between groundwater and surface water: the state of the science. Hydrogeology J 10:52-67

Spens J, Evans AR, Halfmaerten D, Knudsen SW, Sengupta ME, Mak SST, Sigsgaard EE, Hellström M (2017) Comparison of capture and storage methods for aqueous macrobial eDNA using an optimized extraction protocol: advantage of enclosed filter. Methods Ecol Evol 8:635-645

Stevens LE, Meretsky VJ (2008) Aridland springs in North America: ecology and conservation. University of Arizona Press, Arizona

Strayer D (2006) Challenges for freshwater invertebrate conservation. J N Am Benthol Soc 25:271-287

Suhling F, Sahlen G, Martens A, Marais E, Schutte C (2006) Dragonfly assemblages in arid tropical environments. Biodivers Conserv 15:311-332

Taberlet P, Coissac E, Hajibabaei M, Rieseberg LH (2012) Environmental DNA. Mol Ecol 21:1789-1793

Tagestad JD, Brooks ML, Cullinan VI, Downs JL, McKinley R (2016) Precipitaton regime classification for the Mojave Desert: implications for fire occurrence. J Arid Environ 124:388-397

Thompson DG (1921) Routes to Desert Watering Places in the Mohave Desert Region, California. U.S. Geological Survey Water-Supply Paper 490-B.

Unmack PJ, Minckley WL (2008) The demise of desert springs. In: Stevens LE, Meretsky VJ (eds) Aridland springs in North America: ecology and conservation. University of Arizona Press, Tucson

Vicuna S, Maurer EP, Joyce B, Dracup JA, Purkey D (2007) The sensitivity of California water resources to climate change scenarios. J Am Water Resour Assoc 43:482-498

Wangensteen OS, Palacín C, Guardiola M, Turon X (2018) DNA metabarcoding of littoral hard-bottom communities: high diversity and database gaps revealed by two molecular markers. PeerJ 6:e4705

Wynn MR (1963) Desert Bonanza: Early Randsburg - Mojave Desert Mining Camp. Arthur H, Clark Company

Zdon A, Davisson ML, Love AH (2018) Understanding the source of water for selected springs within Mojave Trails National Monument, California. Environ Forensics 19:99-111

Zektser S, Loáiciga HA, Wolf JT (2005) Environmental impacts of groundwater overdraft: selected case studies in the southwestern United States. Environ Geol 47:396-404

Publisher's Note Springer Nature remains neutral with regard to jurisdictional claims in published maps and institutional affiliations. 